\title{
Towards field trace metal speciation using electroanalytical techniques and tangential ultrafiltration
}

\author{
Adnívia Santos Costa Monteiro ${ }^{\mathrm{a}}$, Corinne Parat ${ }^{\mathrm{b}}$, André Henrique Rosa ${ }^{\mathrm{a}}$, \\ José Paulo Pinheiro ${ }^{\mathrm{c}, \mathrm{d}, *}$ \\ a UNESP, Departamento de Engenharia Ambiental, Sorocaba, SP, Brasil \\ ${ }^{\mathrm{b}}$ Université de Pau et des Pays de l'Adour, CNRS UMR 5254, LCABIE, 64000 Pau, France \\ ${ }^{c}$ CNRS, LIEC, UMR 7360, Vandoeuvre-lès-Nancy F-54501, France \\ d Université de Lorraine, LIEC, UMR 7360, Vandoeuvre-lès-Nancy F-54501, France
}

\section{A R T I C L E I N F O}

\section{Article history:}

Received 14 October 2015

Received in revised form

22 January 2016

Accepted 25 January 2016

Available online 26 January 2016

Keywords:

Trace metal speciation

Cadmium

Tangential ultrafiltration

Stripping chronopotentiometry

AGNES

On-site analysis

\begin{abstract}
A B S T R A C T
In this work we propose a trace metal speciation methodology to determine the total, free and ultrafiltered ( $<1 \mathrm{KDa}$ ) metal fractions using electrochemical methods (SCP and AGNES) and tangential ultrafiltration (UF) experiments that can easily be carried out on-site. We tested our methodology spiking Cadmium ions into two natural waters samples from Itapanhau and Sorocabinha rivers in Sao Paulo State, Brazil. The limits of detection (LOD) was $1.6 \times 10^{-9} \mathrm{M}$ for the total $\mathrm{Cd}^{2+}$ determination performed by Stripping Chronopotentiometry (SCP) in the source and acidified ultrafiltered solution and $1.9 \times 10^{-9} \mathrm{M}$ for the free $\mathrm{Cd}^{2+}$ determination using Absence of gradients and Nernstian equilibrium stripping (AGNES), using a thin mercury film electrode. The total metal determination was performed by SCP in acidified samples and the results compared with graphite furnace atomic absorption spectroscopy (GF-AAS). The SCP results were adequate with a 96\% of recovery from the known metal spike for the 12 samples tested. For the Itapanhau sample the free metal determined by AGNES and the ultrafiltered fraction are identical, while for the Sorocabinha the free metal in the source is significantly smaller than the ultrafiltered fraction, indicating that this sample must be rich in metal complexes with small inorganic ligands that are able to permeate the $1 \mathrm{kDa}$ membrane. The proposed metal speciation methodology validated in the laboratory combining UF and SCP/AGNES is able to be used in on-site experiments providing valid information regarding the total and free metal concentrations and additionally some insight on the role of small inorganic ligands to the metal complexation.
\end{abstract}

(c) 2016 Elsevier B.V. All rights reserved.

\section{Introduction}

The interest of studying trace metal ions in natural waters stems from their toxicity towards microorganisms and accumulation through the food chain. Toxic metallic elements, like $\mathrm{Pb}, \mathrm{Cd}$, $\mathrm{Zn}$ and $\mathrm{Hg}$ are found in trace amounts in environmental waters mostly as a result from anthropogenic activity. Their impact on the environment depends on their concentration and speciation since metals may be present as hydrated cations, dissolved molecular species or as parts of complex mineral particles. The dissolved fraction has a much higher bioavailability than the particulate one, thus a higher toxicity.

Currently the conventional notion in ecotoxicological studies is that the controlling species regarding trace metal bioavailability is

\footnotetext{
* Corresponding author at: Université de Lorraine, LIEC, UMR 7360, Vandoeuvrelès-Nancy F-54501, France.

E-mail addresses: jose-paulo.pinheiro@univ-lorraine.fr, jpinheiualgpt@gmail.com (J.P. Pinheiro).
}

the free hydrated cation (FIAM, BLM) [1]. Since the trace amounts of toxic metal present in natural water are difficult to measure; therefore the free cations are even more challenging, since their concentration often lies on the nanomolar range or below. Natural waters have a plethora of ligands able to bind the metal ions, like dissolved inorganic and organic ligands, colloids, suspended matter and the surfaces of organisms, hence only a small part of the total dissolved metal exists as free hydrated cations [2].

Environmental trace metal analysis is not a simple task due to the complexity of the environmental matrices. Additionally the collection and handling of natural waters samples can further induce changes in the distribution of species prior to laboratory measurements, thus on-site measurements are preferable since they avoid problems due to contamination during sampling and storage, metal adsorption to container walls and instability of metal species during transport and storage prior to measurements.

Over the years an extensive effort has been made to design chemical sensors for on-site measurements and there are several books on chemical sensors for aquatic measurements that describe 
various continuous flow analyzers as well as optical and electrochemical sensors [3]. Nevertheless these methods focus mostly on the determination of total metal; hence at this point there are very few affordable on-site systems for free trace metal quantification at the concentration levels present in natural waters.

In terms of portability for on-site trace metal detection system, electrochemical devices are the most advantageous due to their small size and low energy demand. Stripping electrochemical methods coupled with the correct electrode/flow systems present some of the lowest detection limits available for metal determinations, often as low as a few nmol L ${ }^{-1}$ [4].

Amongst the stripping electrochemical techniques one of the most suited for environmental analysis is Stripping Chronopotentiometry (SCP) [5] especially because the signal is not affected by adsorption of organic species at the surface of the electrode [6].

SCP is a two-step technique composed of a deposition step, where metal ions are reduced at a constant potential and a chosen fixed time, followed by a stripping step, where the amalgamated metal is reoxidized through the application of a constant oxidizing current. When a thin mercury film electrode is used in SCP, the rapid metal transport inside the thin film during stripping means that measurements are performed almost always under conditions of complete depletion which was explored by Parat et al. [7] to use much higher stripping currents and therefore remove the oxygen competition in this step.

AGNES (Absence of Gradients and Nernstian Equilibrium Stripping technique) is an electrochemical technique that measures directly the free metal ion concentration [8]. In the deposition step the amalgamation of the metal in the mercury electrode is allowed to continue until the equilibrium value between oxidized and reduced forms in solution and in the mercury electrode is reached. This equilibrium is set by the deposition potential and follows Nernst equation. When this situation is achieved no concentration gradients will be present, either in solution or in the mercury amalgam and the amount of amalgamated metal will be proportional to the free metal ion concentration in the bulk solution. The main disadvantage of AGNES is the waiting time in the deposition step needed to attain equilibrium, however this might be mitigated by using a thin mercury film electrode to benefit from its larger area to volume ratio [9]. Worth mentioning is also the change in the stripping mode from a simple Cottrell decay to a stripping chronopotentiometry step [10].

Another commonly used approach to study the speciation of metals in natural waters is the fractionation of the sample based on tangential ultrafiltration. The procedure is generally carried out with a low pore size membrane (e.g. $1 \mathrm{kDa}$ ) to distinguish the free species from the colloidal ones. The permeate is generally defined as the free fraction (FF) although the metal cations here may also be complexed with small organic or inorganic ligands that are small enough to pass the membrane $[11,12]$.

It is interesting to compare the free metal ions and the small species able to permeate through the $1 \mathrm{kDa}$ membrane which effectively constitute the most mobile metal fraction in natural waters, thus in this work we propose a methodology to determine the total, free and ultrafiltered $(<1 \mathrm{kDa})$ metal fractions using electrochemical methods and tangential ultrafiltration experiments that could easily be carried out on-site. In this work, this methodology was tested in laboratory by spiking cadmium ions into two natural waters samples from Itapanhau and Sorocabinha rivers in Sao Paulo State, Brazil and the results obtained by the electrochemical techniques were compared with GF-AAS in the source waters and ultrafiltered samples for validation of the methodology.

\section{Materials and methods}

\subsection{Reagents}

Chemicals used in this work were of analytical reagent grade and used as received, unless stated otherwise. Ultrapure milli-Q water (resistivity $18.2 \mathrm{M} \Omega \mathrm{cm}$ ) was employed in all experiments. Nitrogen ( $>99.99 \%$ pure) for the electrochemical experiments and argon ( $>99.99 \%$ pure) for the atomic absorption experiments were provided by White Martins. Standard pH $4.00 \pm 0.02$ and $\mathrm{pH}$ $7.0 \pm 0.2$ solutions were obtained from MS Tecnopon Instrumentação, Brasil. Sterile $0.45 \mu \mathrm{m}$ and $47 \mathrm{~mm}$ diameter acetate of cellulose membranes were used to filtrate the samples. $\mathrm{KH}_{2} \mathrm{PO}_{4}$, $\mathrm{Na}_{2} \mathrm{CO}_{3}$ and $\mathrm{NaHCO}_{3}$ all $1000 \mathrm{mg} \mathrm{L}^{-1}$ were obtained from Merck. Nitric acid 65\% (p.a) and phosphoric acid $85 \%$ (p.a) were purchased from Merck. The standard stock solutions of mercury nitrate $\left(1005 \pm 4 \mathrm{mg} \mathrm{L}^{-1}\right)$, cadmium nitrate $\left(1000 \pm 4 \mathrm{mg} \mathrm{L}^{-1}\right)$, and multi element standard solution G16V ICP $\left(100 \mathrm{mg} \mathrm{L}^{-1}\right.$, NIST-USA rastreable) were purchased from Specsol. Cd(II) solution was prepared from dilution of the certified standard using milli-Q water. Palladium and Magnesium matrix modifiers $\left(10.0 \pm 0.2 \mathrm{~g} \mathrm{~L}^{-1}\right)$ used in GFAAS measurements were purchased from Merck. Sodium nitrate electrolyte solutions (0.1 M) and MES (2-(N-morpholino)ethanesulfonic acid) buffer $\left(0.2 \mathrm{~mol} \mathrm{~L}^{-1}\right)$ were prepared from the solids (Merck). Solutions prepared from nitric acid and sodium hydroxides ( $0.1 \mathrm{M}$ standard, Merck) were used to adjust the $\mathrm{pH}$ when necessary. Ammonium acetate, hydrochloric acid, potassium thiocyanide, potassium chloride (all p.a. from Merck) was used to prepare the solution for the cleaning of the working electrode and re-dissolution of the mercury film. The working electrode was screen-printed using a carbon commercial ink Electrodag ${ }^{\mathbb{E}}$ PF-407A. Tangential ultrafiltration was performed using a regenerated cellulose acetate membrane of $1 \mathrm{kDa}$ and 76 mm diameter (Millipore, Billerica, U.S.A).

\subsection{Equipment}

An Ecochemie Autolab PGSTAT10 potentiostat (controlled by GPES 4.9 software) was used in conjunction with a Metrohm 663VA stand (Metrohm, Switzerland). A three electrode configuration was used comprising a $\mathrm{Hg}$ thin film plated onto a homemade screen-printed electrode as the working electrode, a glassy carbon rod counter electrode (6.1247.000), and an $\mathrm{Ag} / \mathrm{AgCl}$ reference electrode (6.0728.020) with a salt bridge (6.1245.010) all from Metrohm.

A Marconi Instrument (model MA-522) and an Analyzer (model 2A14) combination pH electrode, calibrated with MS tecnopon buffers (Merck) were used to measure $\mathrm{pH}$ in the laboratory.

A Teflon home-made tangential ultrafiltration device was built according to Burba et al. [12] and used in conjunction with a peristaltic pump, Gilson Minipuls 3 with Agilent tygon tubing.

The atomic absorption experiments were carried out in a Varian Zeeman Atomic Absorption Spectrometer model AA240z with a PSD 120 auto sampler, Zeeman correction and graphite furnace with integrated L'vov platform. The hollow cathode lamp was obtained from Agilent $(\lambda=228,8 \mathrm{~nm}(\mathrm{Cd})$ e $\mathrm{i}=10 \mathrm{~mA})$, and the argon flow used was $300 \mathrm{~mL} \mathrm{~min}^{-1}$. The signal was measured in peak integration mode.

An inductively coupled plasma atomic emission spectrometer (ICP-OES) model 700 Agilent Technologies was used to quantify the following elements: $\mathrm{Al}, \mathrm{Co}, \mathrm{Cr}, \mathrm{Cu}, \mathrm{Fe}, \mathrm{Mn}, \mathrm{Ni}$, and $\mathrm{Zn}$. Dissolved organic carbon was determined using an Analytik Jena Carbon Analyzer (model N/C 3100). The field measurements of $\mathrm{pH}$, conductivity and turbidity were performed using a Hanna multiparameter probe model HI9829. UV/vis spectroscopic measures were performed in a spectrophotometer Varian model Cary 50. 


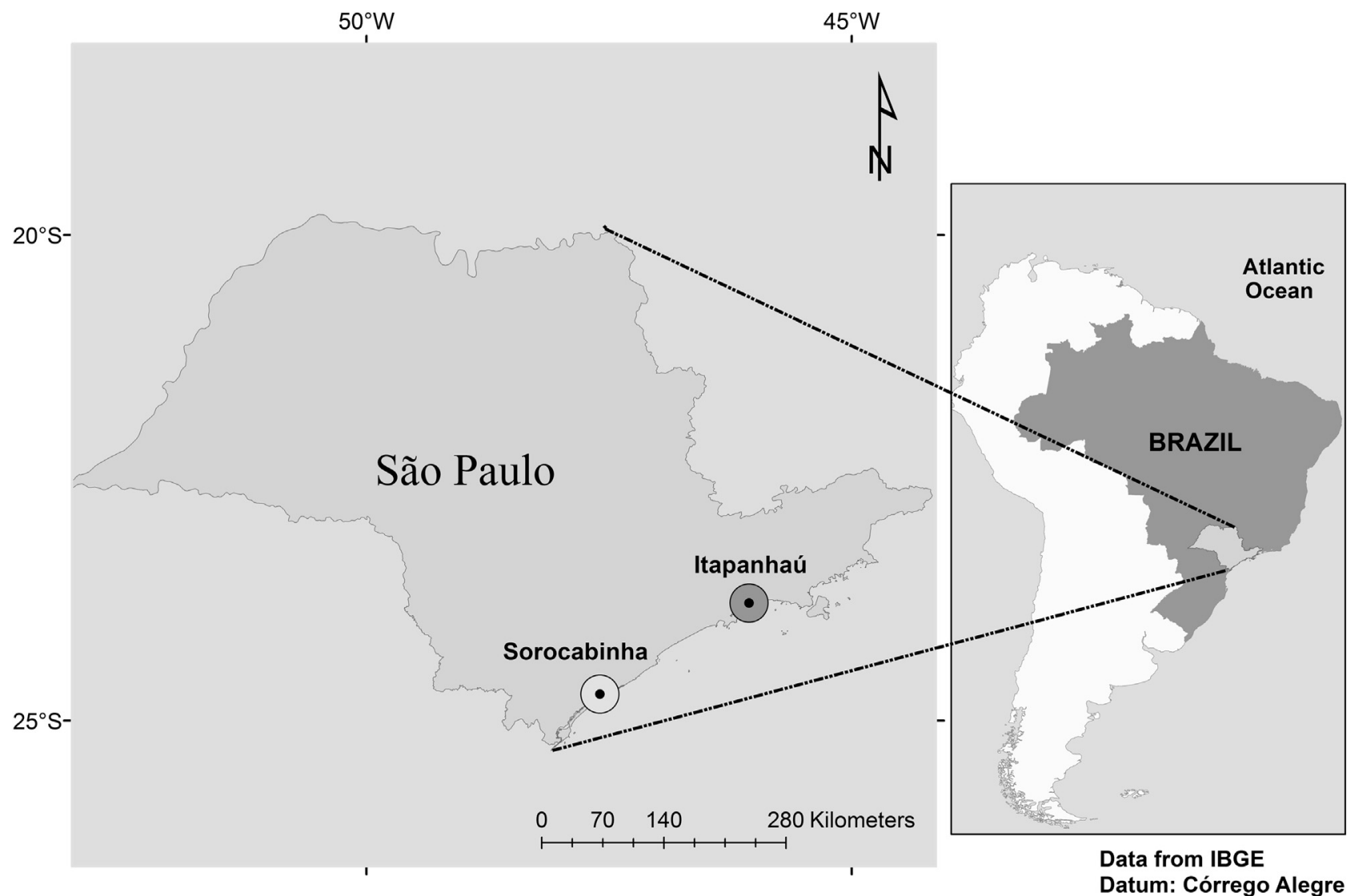

Fig. 1. Map of the state of São Paulo indicating the collection points in the Sorocabinha and Itapanhau rivers.

\subsection{Natural water collection and characterization experiments}

The natural water samples were collected in the Itapanhaú and Sorocabinha Rivers located in São Paulo state in Brazil (Fig. 1) in November 2014. The geographical coordinates of the sampling points are: latitude $24^{\circ} 41^{\prime} 59^{\prime \prime}$ and longitude $47^{\circ} 35^{\prime} 43.68^{\prime \prime}$ for the Itapanhaú river and latitude $23^{\circ} 50^{\prime} 23^{\prime \prime}$ and longitude $46^{\circ} 08^{\prime} 21^{\prime \prime}$ for the Sorocabinha river [16].

The samples were collected from the surface layer using polyethylene flasks which were rinsed thoroughly with the water sample before sampling. The samples were stored at $4{ }^{\circ} \mathrm{C}$ until the analysis. The $\mathrm{pH}$, the conductivity and the dissolved oxygen were measured in situ. Roughly $10 \mathrm{~L}$ of water sample were taken to the laboratory where DOC, sulfate, chloride and dissolved metal were analyzed within $48 \mathrm{~h}$.

Details of ICP-OES analysis, Dissolved organic carbon (DOC) and $\mathrm{UV} / \mathrm{vis}$ Spectroscopy experiments are given in the electronic support information.

\subsection{Graphite furnace atomic spectroscopy (GF-AAS) experiments}

The pyrolysis temperature and atomization temperature for the $\mathrm{Cd}$ measurements in the current samples were 700 and $1600{ }^{\circ} \mathrm{C}$. These values resulted from an optimization procedure using $10 \mu \mathrm{g}$ $\mathrm{Cd}^{2+} \mathrm{L}^{-1}$ (prepared from dilution of the standard solution $\left.1000 \mathrm{mg} \mathrm{L}^{-1}\right)$ in $\mathrm{HNO}_{3} 2 \%(\mathrm{v} / \mathrm{v})$ in presence of the chemical modifiers $5 \mu \mathrm{L} \mathrm{Pd}\left(\mathrm{NO}_{3}\right)_{2}+3 \mu \mathrm{L} \mathrm{Mg}\left(\mathrm{NO}_{3}\right)_{2}$. The calibration plot was carried out for $\mathrm{Cd}^{2+}$ concentrations of $0.89 ; 1.78 ; 4.45 ; 7.12$ and $8.90 \times 10^{-8} \mathrm{~mol} \mathrm{~L}^{-1}$. All measurements were performed in triplicate and when necessary the samples were diluted using milli- $\mathrm{Q}$ water. The obtained LOD and LOQ were respectively $0.6 \mu \mathrm{g} \mathrm{L}^{-1}$ $\left(0.5 \times 10^{-8} \mathrm{~mol} \mathrm{~L}^{-1}\right)$ and $1.9 \mu \mathrm{g} \mathrm{L}^{-1}\left(1.7 \times 10^{-8} \mathrm{~mol} \mathrm{~L}^{-1}\right)$.

\subsection{Tangential ultrafiltration experiments}

Tangential ultrafiltration experiments were carried out using the collected samples from the rivers Itapanhau and Sorocabinha at the natural $\mathrm{pH}$ and ionic strength under constant stirring and $\mathrm{pH}$ monitoring. All measurements were carried out at room temperature $\left(23-26^{\circ} \mathrm{C}\right)$.

Each experiment started with $1 \mathrm{~L}$ of sample water (source) and the system was equilibrated for $15 \mathrm{~min}$ for membrane conditioning using a speed of $6.0 \mathrm{rpm}$. The valve controlling the return flow is then set at $1 \mathrm{~mL} \mathrm{~min}{ }^{-1}$ while the exit valve of the ultrafiltration device was set at a flow of approximately $0.3 \mathrm{~mL} \mathrm{~min}^{-1}$. At this point a $25 \mathrm{~mL}$ aliquot was collected from the source and the collection of first ultrafiltered aliquot (also $25 \mathrm{~mL}$ ) was initiated.

After the first permeate is collected, four additions of standard solution of $\mathrm{Cd}\left(\mathrm{NO}_{3}\right)_{2} 8.9 \times 10^{-4} \mathrm{~mol} \mathrm{~L}^{-1}$ were carried out in order to obtain a total concentration of $\mathrm{Cd}(\mathrm{II})$ of $0.7,1.5,2.4$ and $3.2 \times 10^{-7} \mathrm{~mol} \mathrm{~L}^{-1}$ in the source. Following each addition the source $\mathrm{pH}$ is adjusted back to the original value using $\mathrm{NaOH}$ $1.0 \mathrm{~mol} \mathrm{~L}^{-1}$ due to the small variation induced by the acid present in the standard solution of $\mathrm{Cd}(\mathrm{II})$.

The tests performed on the system showed that a waiting period of $20 \mathrm{~min}$ is necessary to achieve equilibrium prior to the collection of the $25 \mathrm{~mL}$ of sample. At this point the collection of ultrafiltered aliquots is initiated with $5 \mathrm{~mL}$ destined for GF-AAS measurements and $20 \mathrm{~mL}$ for electroanalytical quantification. All metal additions were computed taking into account the volume variation of the source solution.

For the total metal determination using SCP in both, the source and ultrafiltered aliquots, the $20 \mathrm{~mL}$ of solution were acidified with $0.2 \mathrm{~mL}$ de $\mathrm{HNO}_{3} 1.0 \mathrm{~mol} \mathrm{~L}^{-1}$ and subsequently named Source acidified and UF acidified. 


\subsection{Working electrode preparation}

The working electrodes were screen-printed on $1 \mathrm{~mm}$-thick polystyrene support for serigraphy (Sericol) using inks purchased from Acheson Colloids. The electrode was screen-printed and allowed to dry ( $1 \mathrm{~h}$ at room temperature) and cure ( $1 \mathrm{~h}$ in the oven at $60{ }^{\circ} \mathrm{C}$ ). After completion of the screen-printing process, an insulating layer was spread manually over the conductive tracks leaving a working disk area of $9.6 \mathrm{~mm}^{2}$ [10].

Prior to deposition of the $\mathrm{Hg}$ film the screen-printed carbon electrode was conditioned using an electrochemical pre-treatment consisting on fifty successive cyclic voltammetry scans between -0.8 and $+0.8 \mathrm{~V}$ at $0.1 \mathrm{~V} \mathrm{~s}^{-1}$ in $\mathrm{NH}_{4} \mathrm{CH}_{3} \mathrm{COO}\left(1 \mathrm{~mol} \mathrm{~L}^{-1}\right) / \mathrm{HCl}$ $\left(0.5 \mathrm{~mol} \mathrm{~L}^{-1}\right)$ solution [13]. The thin $\mathrm{Hg}$ film was prepared ex-situ in $0.24 \mathrm{mmol} \mathrm{L}^{-1} \mathrm{Hg}$ (II) nitrate in nitric acid $0.73 \mathrm{mmol} \mathrm{L}^{-1}(\mathrm{pH}$ 1.9) by electrodeposition at $-1.3 \mathrm{~V}$ for $700 \mathrm{~s}$ using a rotation rate of the stirrer of $1000 \mathrm{rpm}$. After each working day the charge associated with the deposited $\mathrm{Hg}\left(\mathrm{Q}_{\mathrm{Hg}}\right)$ was determined to assess the state of the mercury film. This was carried out by electronic integration of the linear sweep stripping peak of $\mathrm{Hg}$ with a scan rate $v=0.005 \mathrm{~V} \mathrm{~s}^{-1}$ in $5 \mathrm{mmol} \mathrm{L}^{-1}$ of ammonium thiocyanide ( $\mathrm{pH} 3.4$ ) using a stripping step from $-0.15 \mathrm{~V}$ to $+0.4 \mathrm{~V}$ [9].

\subsection{Electrochemical experiments}

The measurements were performed in triplicate in the laboratory. The solution was purged for $15 \mathrm{~min}$ at the beginning of every experiment and the electrochemical cell was continuously purged over the solution with nitrogen gas during the measurement. All measurements were carried out at room temperature (23-26 ${ }^{\circ} \mathrm{C}$ ). The experiments were carried out in $40 \mathrm{~mL}$ disposable polystyrene (PS) beakers.

A three or four point calibration is daily performed prior to the sample measurements using known metal concentrations in the interval between $3 \times 10^{-9}$ and $3 \times 10^{-7} \mathrm{~mol} \mathrm{~L}^{-1}$. The limits of detection (LOD) and quantification (LOQ) were estimated from the calibrations curve using the following equation:

$\mathrm{LOX}=k S_{\mathrm{y}} / m$

where $k=3$ for the LOD and 10 for the LOQ $b$ is the intercept of the regression line, $S_{\mathrm{y}}$ is the standard deviation of the residuals and $m$ is the slope of the calibration graph.

2.8. Stripping chronopotentiometry experiments in acid media (total metal in the source acidified and UF acidified)

Stripping chronopotentiometry measurements were carried out in $20 \mathrm{~mL}$ acidified source solutions of Cd(II). The experimental conditions used were: deposition potential $-0.78 \mathrm{~V}(v \mathrm{~s} \mathrm{Ag} / \mathrm{AgCl})$, deposition time $\left(t_{\mathrm{d}}\right) 45 \mathrm{~s}$, stripping current $\left(I_{\mathrm{s}}\right) 2.5 \times 10^{-6} \mathrm{~A}$ applied until the potential reached $-0.30 \mathrm{~V}$, rotation speed $1000 \mathrm{rpm}$ (only during the deposition step).

The SCP signal is the characteristic transition time $\tau^{*}$ which is given by [5]:

$\tau^{*}=\frac{I_{\mathrm{d}}^{*} t_{\mathrm{d}}}{I_{\mathrm{s}}=} \frac{\alpha c_{\mathrm{M}, \mathrm{T}}^{*} t_{\mathrm{d}}}{I_{\mathrm{s}}}$

where $I_{d}^{*}$, the limiting diffusion current, is directly proportional to the metal concentration in the bulk $c_{\mathrm{M}, \mathrm{T}}^{*}$.

\subsection{AGNES experiments (free metal in the source)}

Previous to the measurements, the solutions were set at the desired $\mathrm{pH}$ using MES (2-N-morpholino-ethanesulfonic acid) buffer. According to Soares et al. [14] MES does not bind Cd(II). In the case of the Sorocabinha we used the natural ionic strength but for the Itapanhau water sample, the ionic strength was set at $0.010 \mathrm{~mol} \mathrm{~L}^{-1}$ adding $\mathrm{NaNO}_{3}$ and following the conductivity of the solution. This is necessary since a sufficiently high ionic strength ( $\geq 10 \mathrm{mmol} \mathrm{L}^{-1}$ ) and a well buffered system are required to obtain accurate results in AGNES [15].

The free metal ion concentration was determined by the AGNES method according to the procedure developed by Parat et al. [10] where the quantification of the metal amalgamated in the equilibrium step is quantified using a chronopotentiometric measurement. The measurements were performed applying a deposition potential $E_{1}$ of $-0.72 \mathrm{~V}$ for a period of time $t_{1}$ of $240 \mathrm{~s}$. The stripping step was performed by SCP using an oxidizing current $I_{\mathrm{S}}$ of $2.5 \times 10^{-6} \mathrm{~A}$ applied until the potential reached $-0.30 \mathrm{~V}$. The rotation speed used was $1000 \mathrm{rpm}$.

In this implementation the AGNES signal is the charge corresponding to the amalgamated metal in the mercury electrode $Q$ which is given by:

$Q=\tau^{*} I_{s}=h c_{\mathrm{M}}^{*}$

where $\tau^{*}$ is the reoxidation time, $I_{\mathrm{s}}$ is the reoxidation current applied in the stripping step, $h$ is a constant and $c_{\mathrm{M}}^{*}$ is the free metal concentration in the bulk.

\section{Results and discussion}

The proposed methodology for on-site analysis was tested in the laboratory by spiking $\mathrm{Cd}(\mathrm{II})$ ions into two natural waters samples from Itapanhau and Sorocabinha rivers in Sao Paulo StateBrazil. These rivers were chosen due to their different characteristics especially regarding conductivity, since the Sorocabinha sampling is relatively close to the sea..

\subsection{Natural river waters characterization}

Table 1 shows the major parameters that allow us to characterize both rivers. Their $\mathrm{pH}$ and $\mathrm{DOC}$ are quite close, while the conductivity of the Sorocabinha river is much higher than the Itapanhau one due to its proximity to the ocean. This is also reflected in the higher contents of major cations like $\mathrm{K}^{+}, \mathrm{Mg}^{2+}$ and $\mathrm{Ca}^{2+}$ and anions like $\mathrm{Cl}^{-}$. Cadmium, $\mathrm{Pb}, \mathrm{Co}$ and $\mathrm{Ni}$ are below the detection limit in both rivers, a small amount of both $\mathrm{Cu}$ and $\mathrm{Cr}$

Table 1

Sorocabinha and Itapanhau rivers characterization.

\begin{tabular}{|c|c|c|}
\hline & Itapanhau & Sorocabinha \\
\hline pH & 6.2 & 6.7 \\
\hline Conductivity $\left(\mu \mathrm{Sm}^{-1}\right)$ & 189 & 1043 \\
\hline$D O C\left(m g L^{-1}\right)$ & 14.0 & 16.8 \\
\hline Turbidity (NTU) & 3.7 & 6.1 \\
\hline Dissolved oxygen $\left(m g O L^{-1}\right)$ & 1.8 & 1.4 \\
\hline $\mathrm{Cl}^{-}\left(\mathrm{mol} \mathrm{L}^{-1}\right)$ & $3.6 \times 10^{-4}$ & $8.5 \times 10^{-4}$ \\
\hline $\mathrm{SO}_{4}{ }^{2-}\left(\mathrm{mol} \mathrm{L}^{-1}\right)$ & $5.0 \times 10^{-6}$ & $2.2 \times 10^{-6}$ \\
\hline $\mathrm{Al}\left(\mathrm{mol} \mathrm{L}^{-1}\right)$ & $4.9 \times 10^{-6}$ & $1.5 \times 10^{-6}$ \\
\hline $\mathrm{Ca}\left(\mathrm{mol} \mathrm{L}^{-1}\right)$ & $4.2 \times 10^{-5}$ & $3.0 \times 10^{-4}$ \\
\hline $\mathrm{Cd}\left(\mathrm{mol} \mathrm{L}^{-1}\right)$ & $<L O D$ & $<$ LOD \\
\hline $\mathrm{Co}\left(\mathrm{mol} \mathrm{L}^{-1}\right)$ & $<L O D$ & $<$ LOD \\
\hline $\mathrm{Cr}\left(\mathrm{mol} \mathrm{L}^{-1}\right)$ & $<L O D$ & $6.5 \times 10^{-9}$ \\
\hline $\mathrm{Cu}\left(\mathrm{mol} \mathrm{L}^{-1}\right)$ & $<L O D$ & $3.7 \times 10^{-8}$ \\
\hline $\mathrm{Fe}\left(\mathrm{mol} \mathrm{L}^{-1}\right)$ & $13.0 \times 10^{-6}$ & $6.1 \times 10^{-6}$ \\
\hline$K\left(\mathrm{~mol} \mathrm{~L}^{-1}\right)$ & $5.5 \times 10^{-5}$ & $2.1 \times 10^{-4}$ \\
\hline $\operatorname{Mg}\left(\mathrm{mol} \mathrm{L}^{-1}\right)$ & $6.7 \times 10^{-5}$ & $8.4 \times 10^{-4}$ \\
\hline $\mathrm{Mn}\left(\mathrm{mol} \mathrm{L}^{-1}\right)$ & $1.3 \times 10^{-6}$ & $1.9 \times 10^{-6}$ \\
\hline $\mathrm{Ni}\left(\mathrm{mol} \mathrm{L}^{-1}\right)$ & $<L O D$ & $<$ LOD \\
\hline $\mathrm{Pb}\left(\mathrm{mol} \mathrm{L}^{-1}\right)$ & $<L O D$ & $<$ LOD \\
\hline $\mathrm{Zn}\left(\mathrm{mol} \mathrm{L}^{-1}\right)$ & $2.3 \times 10^{-8}$ & $2.0 \times 10^{-7}$ \\
\hline
\end{tabular}


Table 2

Ratio $A_{254} / A_{436}$ for the Itapanhaú and Sorocabinha water samples.

\begin{tabular}{|c|c|c|c|}
\hline & & Sorocabinha & Itapanhaú \\
\hline \multirow[t]{2}{*}{ Absorbance } & $254 \mathrm{~nm}$ & 0.81 & 0.79 \\
\hline & $436 \mathrm{~nm}$ & 0.07 & 0.07 \\
\hline \multirow[t]{2}{*}{ Ratio } & $\mathrm{A}_{254} / \mathrm{A}_{436}$ & & 11.3 \\
\hline & & & \\
\hline
\end{tabular}

appears in the Sorocabinha, while $\mathrm{Zn}$ appears in both.

Table 2 reports the UV/vis spectroscopic ratio $\left(A_{254} / A_{436}\right)$, i.e. the absorption values taken at 254 and $436 \mathrm{~nm}$ in the UV/vis spectra, which is a semi-quantitative method to characterize humic substances in natural waters. This ratio is used as an indicator of the origin and the modifications of natural organic matter in aqueous systems. For instance, absorbance at $254 \mathrm{~nm}$ is typical for aromatic groups. Due to the absorption of visible light by humic acids, this ratio rises with increasing contents of humic acids in solution. These two samples showed very similar values, which means that the origin of their dissolved organic matter is likely similar.

\subsection{Proposed analytical methodology for on-site analysis}

The methodology proposed is depicted in Fig. 2. A sample is collected and filtered through a $0.45 \mu \mathrm{m}$ filter to separate the particulate and dissolved fractions. Three different treatments are applied on the filtered fraction: (a) the filtered fraction is acidified with $\mathrm{HNO}_{3}$ before being analyzed by SCP to get the total dissolved metal concentration, (b) the filtered fraction is directly analyzed by using the AGNES method to get the free metal concentration and (c) the filtered fraction is ultrafiltered at $1 \mathrm{kDa}$ then acidified with $\mathrm{HNO}_{3}$ before being analyzed by SCP to get the metal concentration including both, the free metal ion and the metal complexed to small ligands. For each fraction, the $\mathrm{pH}$, the conductivity and the temperature are measured and aliquots are then taken for different analyses.

Total metal determination: First the electroanalytical system is calibrated to obtain the value of the proportionality constant; $\alpha$ (Eq. (2)) using three or four metal additions measured in triplicate. The calibration solution is prepared using $20 \mathrm{~mL} \mathrm{NaNO}$ at the same conductivity as the sample concentrations, which is then acidified by addition of $0.1 \mathrm{~mL}$ of $\mathrm{HNO}_{3} 1 \mathrm{~mol} \mathrm{~L}^{-1}$.

Following the calibration procedure the electrodes are thoroughly cleaned using milli-Q water and the polystyrene beaker is changed. One aliquot of $20 \mathrm{~mL}$ of sample is placed directly in the PS beaker and acidified with $0.1 \mathrm{~mL}$ of $\mathrm{HNO}_{3} 1 \mathrm{~mol} \mathrm{~L}^{-1}$ after which the total metal is measured in triplicate.

Ten calibration curves were measured in the range $3 \times 10^{-9}$ $-1 \times 10^{-7} \mathrm{~mol} \mathrm{~L}^{-1}$ for which the LOD obtained was in the interval 0.8 to $2.4 \times 10^{-9}$ and seven calibration curves were taken in the range $3 \times 10^{-9}$ to $1 \times 10^{-7} \mathrm{~mol} \mathrm{~L}^{-1}$ to $3 \times 10^{-7} \mathrm{~mol} \mathrm{~L}^{-1}$ yielding LOD in the interval $3.6-9.8 \times 10^{-9}$ which is of the same order of magnitude than the LOD obtained for GF-AAS $\left(5.0 \times 10^{-9} \mathrm{~mol} \mathrm{~L}^{-1}\right)$. Note that these values were obtained for a deposition time of $45 \mathrm{~s}$, hence they can still be improved by a significant margin since traditionally deposition times used in anodic stripping voltammetry range between 60 and $600 \mathrm{~s}$, as long as the blank solution has no metal impurities.

Free metal determination: the first step is the verification of the equilibrium condition for AGNES measurements for the chosen deposition potential. This should be done regularly due to possible variations in the potential of the reference electrode. A serie of measurements is done using different deposition times, usually from $30 \mathrm{~s}$ to $360 \mathrm{~s}$ and the equilibrium conditions are reached when the reoxidation time becomes the same for increasing deposition time [8]. After this step a calibration is performed to obtain the value of the proportionality constant; $h$ (Eq. (3)) using three or four metal additions measured in triplicate. The calibration solution is prepared using $20 \mathrm{~mL} \mathrm{NaNO}$ at the same ionic strength as the sample concentrations (being the minimum value used of $10 \mathrm{mmol} \mathrm{L}^{-1}$ ) and adding $1 \mathrm{mmol} \mathrm{L}^{-1}$ of a suitable buffer.

Following the calibration procedure, the electrodes are thoroughly cleaned using milli-Q water and the PS beaker is changed. One aliquot of $20 \mathrm{~mL}$ of sample is placed directly in the PS beaker, then the buffer is added (set to a final concentration of $1 \mathrm{mmol} \mathrm{L}^{-1}$ ) and if necessary the ionic strength is set to $10 \mathrm{mmol} \mathrm{L}^{-1}$ by addition of $\mathrm{NaNO}_{3} 1 \mathrm{~mol} \mathrm{~L}^{-1}$ and then the free metal is measured in triplicate.

Nine calibration curves were measured in the range $0.65 \times 10^{-9}-1 \times 10^{-7} \mathrm{~mol} \mathrm{~L}^{-1}$ for which the LOD obtained was in the interval $0.7-3.6 \times 10^{-9} \mathrm{~mol} \mathrm{~L}^{-1}$, which is a noteworthy result since this is the detection limit for the free metal and should be compared with the values obtained for ion selective electrodes (ISE) which are usually two to three orders of magnitude higher. In contrast this value will not be easier to improve ever since we are already operating at a deposition potential close to the limiting current.

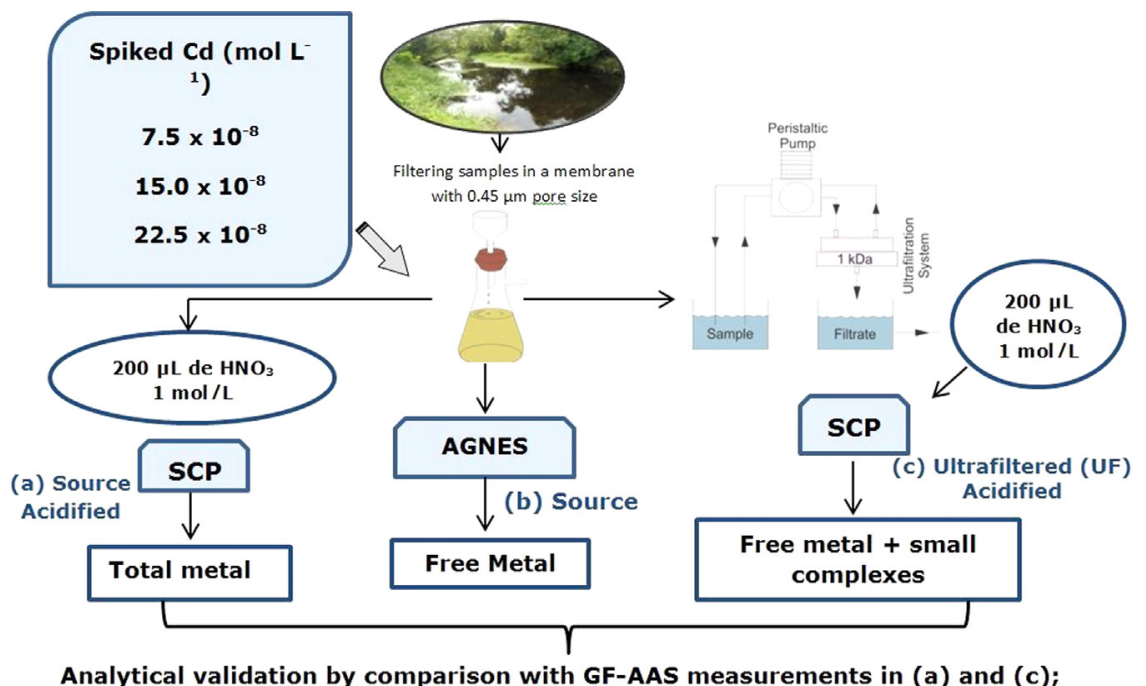

Fig. 2. Schema of the proposed analytical methodology for on-site analyses. 


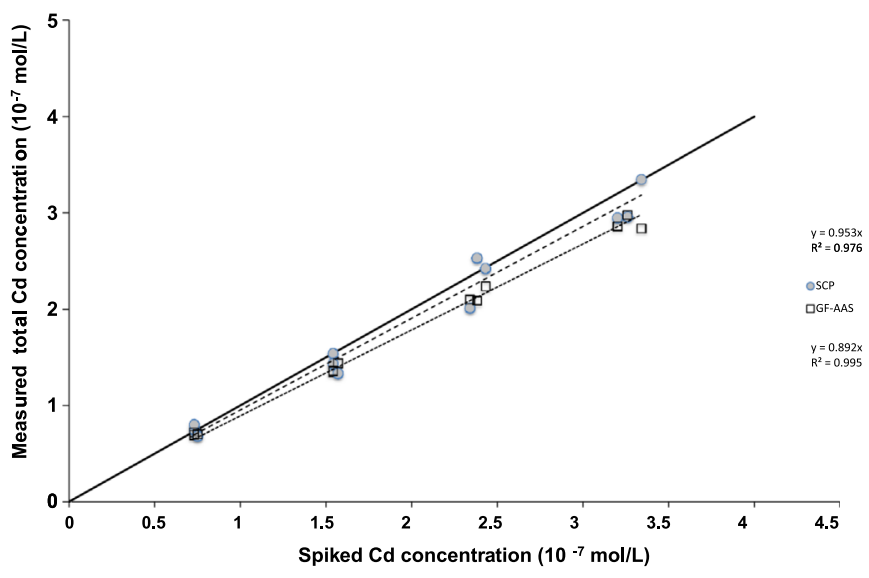

Fig. 3. Comparison of the SCP and GFAAS total measured metal with the real spiked concentration.

Tangential ultrafiltration ( $1 \mathrm{KDa}$ ): free metal and small complexes: The membrane is conditioned for 15 min with the source solution and the return and ultrafiltrated flow valves are set to 1 and $0.3 \mathrm{~mL} \mathrm{~min}^{-1}$ respectively. $25 \mathrm{~mL}$ of ultrafiltered solution are collected and $5 \mathrm{~mL}$ are taken for the GF-AAS measurements. The remaining $20 \mathrm{~mL}$ are acidified with $0.1 \mathrm{~mL}$ of $\mathrm{HNO}_{3} 1 \mathrm{~mol} \mathrm{~L}^{-1}$ after which their metal concentrations are measured in triplicate by SCP.

The determination of total metal and ultrafiltered metal performed by SCP is validated by comparison with the samples measured by GF-AAS.

\subsection{Total metal determination in the source solution}

Due to the absence of $\mathrm{Cd}$ in the natural water samples, four spikes of Cd of approximately $0.7,1.5,2.4$ and $3.2 \times 10^{-7} \mathrm{~mol} \mathrm{~L}^{-1}$, were carried out in each experiment. Fig. 3 shows the concentrations, percentage of recovery and differences obtained by SCP and GFAAS in two spiked natural water solutions from Sorocabinha and one from Itapanhau rivers.

The \% of recovery obtained for SCP is quite good averaging $96 \%$ in a range varying from $85 \%$ to $109 \%$ while for GF-AAS are slightly worse with an average of $91 \%$ in an interval from $85 \%$ to $97 \%$. These percentages of recovery are quite good since these environmental matrices are often difficult to measure reproducibly (Table B in Electronic Support information).

The slope values in Fig. 3 show that SCP (0.953) is slightly more accurate than GFAAS (0.892) while the correlation coefficient values show that SCP is less precise than GFAAS (0.976 vs 0.995). These results confirm the SCP ability to accurately determine the total metal in these spiked natural samples.

In the electrochemical measurements, no destruction of the organic matter was necessary for the total metal determination which is probably due to the weak binding of $\mathrm{Cd}(\mathrm{II})$ to the organic matter, which are mostly from the fulvic acid fractions. For other metals like $\mathrm{Cu}$ (II) or $\mathrm{Pb}$ (II) this simplification of the methodology assumed here must be validated.

\subsection{Ultrafiltered $(<1 \mathrm{kDa})$ metal determination}

Table 3 shows the metal concentrations measured by SCP and GFAAS in the filtered solution for four experiments carried out in the Sorocabinha and Itapanhau rivers. First the results obtained for the two replicas are in good agreement. A second observation is that the results obtained by SCP and GFAAS are mostly concordant, with the exception of the three GFAAS points marked with asterisks. Again the results obtained by SCP in an acid media are in
Table 3

Tangential UF free Cd and small complexes metal measured by SCP and GFAAS in acidified solutions.

\begin{tabular}{|c|c|c|c|c|c|}
\hline $\begin{array}{l}\text { Spiked total } \\
\text { metal } \\
\text { source } \\
\left(10^{-7} \mathrm{M}\right)\end{array}$ & $\begin{array}{l}\operatorname{UF~SCP~}(\mathrm{M}) \\
\left(10^{-7} \mathrm{M}\right)\end{array}$ & $\begin{array}{l}\text { UF AAS } \\
(\mathrm{M}) \\
\left(10^{-7} \mathrm{M}\right)\end{array}$ & $\begin{array}{l}\text { Total metal } \\
\text { Source } \\
\left(10^{-7} \mathrm{M}\right)\end{array}$ & $\begin{array}{l}\operatorname{UF~SCP~(M)~} \\
\left(10^{-7} \mathrm{M}\right)\end{array}$ & $\begin{array}{l}\text { UF AAS (M) } \\
\left(10^{-7} \mathrm{M}\right)\end{array}$ \\
\hline \multicolumn{3}{|l|}{ Itapanhau 1} & \multicolumn{3}{|l|}{ Itapanhau 2} \\
\hline 0.7 & 0.3 & 0.2 & 0.7 & 0.3 & 0.2 \\
\hline 1.5 & 0.5 & 0.5 & 1.5 & 0.4 & 0.5 \\
\hline 2.4 & 1.0 & 0.9 & 2.4 & 0.9 & 0.9 \\
\hline 3.2 & 1.3 & $0.9^{\mathrm{a}}$ & 3.2 & 1.3 & $1.0^{\mathrm{a}}$ \\
\hline \multicolumn{3}{|c|}{ Sorocabinha 1} & \multicolumn{3}{|c|}{ Sorocabinha 2} \\
\hline 0.7 & 0.4 & 0.5 & 0.7 & 0.5 & 0.5 \\
\hline 1.5 & 0.9 & 0.9 & 1.5 & 0.8 & $1.1^{\mathrm{a}}$ \\
\hline 2.4 & 1.4 & 1.4 & 2.4 & 1.3 & 1.5 \\
\hline 3.2 & 1.8 & 1.9 & 3.2 & 1.8 & 2.0 \\
\hline
\end{tabular}

a Points in disagreement.

good agreement with the GFAAS confirming the good performance of this technique.

An interesting result is that although the DOC contents and $\mathrm{pH}$ are quite similar for both samples, the metal measured in the ultrafiltrated samples is significantly higher for the Sorocabinha than for the Itapanhau samples.

\subsection{Free metal determination in the source solution}

Fig. $4 \mathrm{a}$ and $\mathrm{b}$ shows the comparison of the total (spiked) metal with both the metal determined in the ultrafiltered samples and
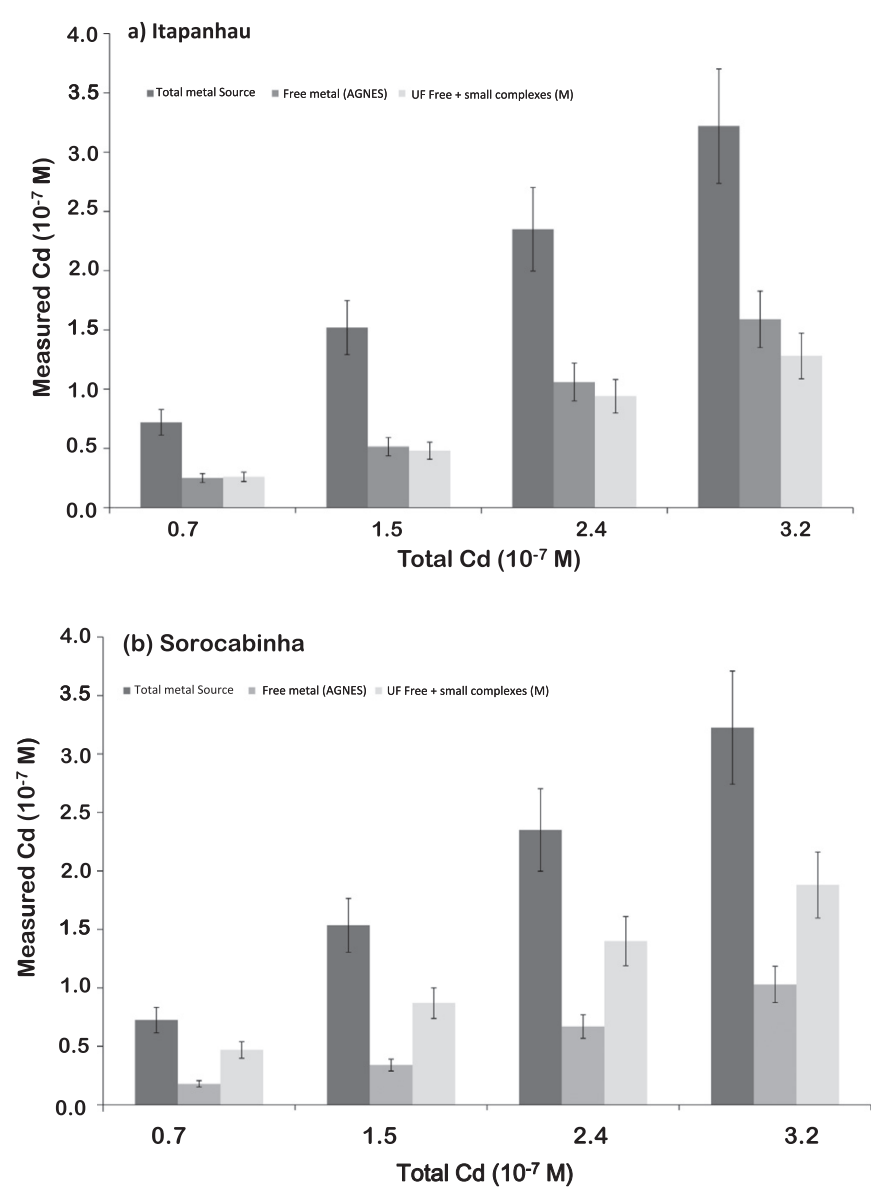

Fig. 4. Comparison of the total (spiked) metal with both the metal determined in the ultrafiltered samples and the free metal determined directly in the Itapanhau (a) and Sorocabinha (b) rivers samples. 
the free metal determined directly in the Itapanhau (a) and Sorocabinha (b) river samples. The free metal is determined directly in the river solution by AGNES and upon comparison with the free plus small metal complexes measured in the ultrafiltered samples. Three interesting results are evident: i) for the Itapanhau the free metal fraction determined by AGNES and the ultrafiltered fraction are quite similar; ii) for the Sorocabinha the free metal is significantly smaller than the metal measured in the ultrafiltered fraction; iii) the metal concentration in the ultrafiltered fraction of the Sorocabinha is roughly twice that of the Itapanhau while its free metal in the source is actually smaller.

Starting from the first observation the agreement between the free and ultrafiltered fraction for the Itapanhau River is quite remarkable indicating that apart from the natural organic matter, represented by the DOC there are few small inorganic ligands in solution that are able to permeate the $1 \mathrm{kDa}$ membrane. Regarding the methodology, this is an interesting observation since the agreement between ultrafiltered and free metal determinations implies a negligible contribution from small inorganic ligands for the metal binding.

The second observation means that the Sorocabinha River must be more concentrated in small inorganic ligands that are able to permeate the $1 \mathrm{kDa}$ membrane, so that the metal content measured in the ultrafiltered fraction is higher than the free metal content measured in the source. This is supported by the much higher conductivity of the Sorocabinha $\left(1043 \mu \mathrm{S} \mathrm{cm}^{-1}\right)$ as compared with the Itapanhau $\left(189 \mu \mathrm{S} \mathrm{cm}^{-1}\right)$.

The third observation suggests that the $\mathrm{Cd}$ speciation is different in both river samples being controlled mostly by the organic matter in the Itapanhau River while in the Sorocabinha river the small inorganic ligands and the competition from other cations, namely a roughly $10 \times$ higher concentration of calcium and magnesium ions in solution must be taken into account. Note that for Cd binding with DOC is mostly electrostatic so the competition of $\mathrm{Ca}$ and $\mathrm{Mg}$ is very effective. Regarding the DOC even if the concentration is similar in both rivers the nature of the organic matter present might be different, namely in the relative amounts of fulvic and humic fractions present. The higher ionic strength and the cations present in the Sorocabinha mean that the humic fraction of the DOC will be less stable or already coagulated where in the Itapanhau this humic fraction can still be significant. In future works we plan to investigated this issue in detail.

To confirm these observations we carried out an AGNES measurement in the non-acidified ultrafiltered fraction of two Sorocabinha river samples (spiked at 2.4 and $3.2 \times 10^{-7} \mathrm{~mol} \mathrm{~L}^{-1}$ ) to determine the free $\mathrm{Cd}$ proportion in the ultrafiltered solution. The results showed that only $37-45 \%$ of the total Cd of this fraction is free, thus confirming the metal is indeed complexed in the nonacidified ultrafiltered sample, most likely by small inorganic ligands.

We validated both the SCP total $\mathrm{Cd}^{2+}$ determination in the source and acidified ultrafiltered solution with a LOD of $1.6 \times 10^{-9} \mathrm{M}$ and the AGNES free $\mathrm{Cd}^{2+}$ determination with a LOD of $1.9 \times 10^{-9} \mathrm{M}$. We demonstrated that the proposed metal speciation methodology is able to provide valid information regarding the total and free metal while being able to additionally afford some insight on the contribution of small inorganic ligands to the metal complexation in the source.

We plan to follow this proof-of-concept with the development of the same methodology for other metals like $\mathrm{Pb}$ and $\mathrm{Zn}$ and their mixtures, to further investigate the nature of the DOC in both rivers and finally to apply this methodology on-site and obtain experimental data to model the binding of metal ions in these rivers.

\section{Acknowledgment}

The authors acknowledge the support of FAPESP and CNPq (Brazilian Agencies) and the support from the French National Research Agency ANR Species (ANR) and the Portuguese National Funding Agency For Science, Research and Technology (FCT-ANR/ AAG-MAA/0065/2012 and Blanc International II-SIMI 6-Système Terre environnement risques SPECIES). A.S.C. Monteiro acknowledges a PhD grant from FAPESP/Brazil and A.H. Rosa/J.P. Pinheiro acknowledges a visiting grant from CNPq/Brazil (PVE 400572/ 2013-3).

\section{Appendix A. Supplementary material}

Supplementary data associated with this article can be found in the online version at http://dx.doi.org/10.1016/j.talanta.2016.01. 053.

\section{References}

[1] D.M. Di Toro, H.E. Allen, H.L. Bergman, J.S. Meyer, P.R. Paquin, R.C. Santore, Biotic ligand model of the acute toxicity of metals. 1. Technical basis, Environ. Toxicol. Chem. 20 (10) (2001) 2383-2396.

[2] J. Buffle, Complexation Reactions in Aquatic Systems: An Analytical Approach, Ellis Horwood, Chichester, 1988.

[3] J. Buffle, G. Horvai, In Situ Monitoring of Aquatic Systems: Chemical Analysis and Speciation, John Wiley \& Sons, New York, 2000.

[4] A.M. Mota, J.P. Pinheiro, M.L. Simoes Goncalves, Electrochemical methods for speciation of trace elements in marine waters. Dynamic Aspects, J. Phys. Chem. A 116 (25) (2012) 6433-6442.

[5] R.M. Town, H.P. van Leeuwen, Fundamental features of metal ion determination by stripping chronopotentiometry, J. Electroanal. Chem. 509 (1) (2001) $58-65$.

[6] R.M. Town, H.P. van Leeuwen, Effects of adsorption in stripping chronopotentiometric metal speciation analysis, J. Electroanal. Chem. 523 (1-2) (2002) 1-15.

[7] C. Parat, A. Schneider, A. Castetbon, M. Potin-Gautier, Determination of trace metal speciation parameters by using screen-printed electrodes in stripping chronopotentiometry without deaerating, Anal. Chim. Acta 688 (2) (2011) $156-162$.

[8] J. Galceran, E. Companys, J. Puy, J. Cecilia, J.L. Garces, AGNES: a new electroanalytical technique for measuring free metal ion concentration, J. Electroanal. Chem. 566 (1) (2004) 95-109.

[9] L.S. Rocha, E. Companys, J. Galceran, H.M. Carapuca, J.P. Pinheiro, Evaluation of thin mercury film rotating disk electrode to perform absence of gradients and Nernstian equilibrium stripping (AGNES) measurements, Talanta 80 (5) (2010) 1881-1887.

[10] C. Parat, L. Authier, D. Aguilar, E. Companys, J. Puy, J. Galceran, M. PotinGautier, Direct determination of free metal concentration by implementing stripping chronopotentiometry as the second stage of AGNES, Analyst 136 (20) (2011) 4337-4343.

[11] P. Burba, J. Rocha, D. Klockow, Labile complexes of trace-metals in aquatic humic substances-investigations by means of an ion exchange-based flow procedure, Fresenius J. Anal. Chem. 349 (12) (1994) 800-807.

[12] P. Burba, J. Van den Bergh, D. Klockow, On-site characterization of humic-rich hydrocolloids and their metal loading by means of mobile size-fractionation and exchange techniques, Fresenius J. Anal. Chem. 371 (5) (2001) 660-669.

[13] S.C.C. Monterroso, H.M. Carapuca, J.E.J. Simao, A.C. Duarte, Optimisation of mercury film deposition on glassy carbon electrodes: evaluation of the combined effects of $\mathrm{pH}$, thiocyanate ion and deposition potential, Anal. Chim. Acta 503 (2) (2004) 203-212.

[14] H. Soares, P. Conde, A. a N. Almeida, M. Vasconcelos, Evaluation of n-substituted aminosulfonic acid $\mathrm{pH}$ buffers with a morpholinic ring for cadmium and lead speciation studies by electroanalytical techniques, Anal. Chim. Acta $394(2-3)$ (1999) 325-335.

[15] D. Aguilar, C. Parat, J. Galceran, E. Companys, J. Puy, L. Authier, M. PotinGautier, Determination of free metal ion concentrations with AGNES in low ionic strength media, J. Electroanal. Chem. 689 (2013) 276-283.

[16] D. Goveia, J.C. Rocha, L.C. de Oliveira, L.C. de Morais, V. de Campos, L.F. Fraceto, A.H. Rosa, Structural caracterization of aquatic humic substance extracted from Itapanhau and Ribeira De Iguape Rivers, Quimica Nova 34 (5) (2011) 753-U31. 